\title{
Removal of cationic pollutants from water by xanthated corn cob: optimization, kinetics, thermodynamics and prediction of purification process
}

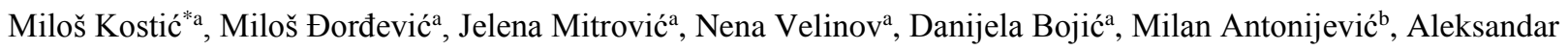
Bojića $^{a}$

aDepartment of Chemistry, Faculty of Science and Mathematics, University of Niš, Višegradska 33, 18000 Niš, Serbia ${ }^{\mathrm{b}}$ School of Science, University of Greenwich, Chatham Maritime, Kent, ME4 4TB, UK

*Corresponding author: Tel.: +3816348 44 75; fax: +381 16260437.

E-mail address: mk484475@gmail.com (M. Kostić)

Postal addreess: Department of Chemistry, Faculty of Sciences and Mathematics, University of Niš, Visegradska 33, 18000 Niš, Serbia 


\begin{abstract}
The removal of $\mathrm{Cr}(\mathrm{III})$ ions and methylene blue (MB) from aqueous solutions by xanthated corn cob (xCC) in batch conditions was investigated. The sorption capacity of $\mathrm{xCC}$ strongly depended of the $\mathrm{pH}$, and increase when the $\mathrm{pH}$ rises. The kinetics was well fitted by pseudo-second order and Chrastil's model. Sorption of Cr(III) ions and MB on $\mathrm{xCC}$ was rapid during the first $20 \mathrm{~min}$ of contact time and, thereafter, the biosorption rate decrease gradually until reaching equilibrium. The maximum sorption capacity of 17.13 and $83.89 \mathrm{mg} \mathrm{g}^{-1}$ for $\mathrm{Cr}(\mathrm{III})$ ions and $\mathrm{MB}$, respectively was obtained at $40^{\circ} \mathrm{C}, \mathrm{pH} 5$ and sorbent dose $4 \mathrm{~g} \mathrm{dm}^{-3}$ for removal of $\mathrm{Cr}(\mathrm{III})$ ions and $1 \mathrm{~g} \mathrm{dm}^{-3}$ for removal of MB. The prediction of purification process was successfully carried out and the verification of theoretically calculated amounts of sorbent was confirmed by using packed-bed column laboratory system with recirculation of the aqueous phase. The wastewater from chrome plating industry was successfully purified, i.e. after 40 min concentration of $\mathrm{Cr}$ (III) ions was decreased lower than $0.1 \mathrm{mg} \mathrm{dm}^{-3}$. Also, removal of $\mathrm{MB}$ from the river water was successfully carried out and after 40 min removal efficiency was about $94 \%$.
\end{abstract}

Keywords: xanthated biomaterial, $\mathrm{Cr}(\mathrm{III})$, methylene blue, sorption, thermodynamics, wastewater

\title{
1. Introduction
}

Heavy metals are toxic pollutants and non-biodegradable, which can accumulate in living tissues causing various diseases and disorders. Apart the aesthetic problems the greatest environmental concern with dyes is their inhibitory effect on photosynthesis in aquatic ecosystems. The effective removal of heavy metals and dyes from aqueous waste is among the most important issues of the world. Electroplating, leather tanning and dyeing, mining or pigment, wood preservation, battery manufacturing and textile industries are examples of industries that release a high volume of wastewater containing heavy metals and dyes into the environment and aquatic ecosystems. Trivalent chromium, $\mathrm{Cr}$ (III) is required for metabolism sugar and fat metabolism in organisms (Anderson 2001), but long time exposure causes skin allergic and cancer (Gupta et al. 2011; Rajurkar et al. 2011; Yun et al. 2001). Methylene blue is a thiazine (cationic) dye, it is not regarded as acutely toxic, but it has various harmful effects (eye burns, may cause nausea, vomiting and gastritis problems) (Haque et al. 2002).

The most common method for heavy metal removal from wastewater is chemical precipitation. Low chromium content in water leads to an increase of precipitant in the process of chromium removal. Furthermore, the precipitation process generates the toxic sludge that has to be dewatered, stabilized and disposed of. Chromium will only precipitate in the trivalent form and thus it must be reduced from its hexavalent form prior to precipitation. Hexavalent chromium reduction is achieved at low $\mathrm{pH}$ levels $(\sim 2-3)$ with a reducing agent-usually sodium metabisulfite or ferrous sulfite (Naja and Volesky 2009).

If the $\mathrm{pH}$ is maintained between 8.2 and 8.6 , then the trivalent chrome will be precipitated as the hydroxide. This method produces an effluent containing trivalent chromium between 2 and $5 \mathrm{mg} \mathrm{dm}^{-3}$ (Bennett 2001). Trivalent chromium cannot be removed by precipitation below the maximum permissible limits. The US Environmental Protection Agency (EPA) and The World Health Organization (WHO) recommended the maximum permissible limits of chromium (as total chromium) in drinking water of 0.1 and $0.05 \mathrm{mg} \mathrm{dm}^{-3}$, respectively (Rajput and Pittman 2015). Among the various water treatment techniques, sorption is generally preferred for the removal of heavy metal ions and other hazardous materials, especially at the concentrations ranging from 1 to $100 \mathrm{mg} \mathrm{dm}^{-3}$, because of its high efficiency, minimization of chemicals, easy handling, availability of different sorbents, cost effectiveness and higher effectiveness than the conventional methods such as chemical precipitation and ion exchange (Schiewer and Volesky 1995). Sorption is a physico-chemical process by which one substance becomes attached to another (Michalak et al. 2013). Biosorbent or biological matrix has been proposed as one of the most promising technologies for the removal of heavy metal and dyes ions from wastewaters (Wang and Chen 2009). In recent years, a number of agricultural and forestry by-products such as Soybean meal (Witek-Krowiak 2013), saltbush (Atriplex canescens) (Sawalha et al. 2006), blue-green algae Spirulina sp. (Chojnacka et al. 2005), rose petals biomass (Iftikhar et al. 2009), bacterial dead 
Streptomyces rimosus biomass (Selatnia and Bakhti 2005) have been used for the removal of $\mathrm{Cr}$ (III) ions from water solution. Methylene blue is selected as a model compound in order to evaluate the capacity of biosorbent. Many textile manufacturers use and release aromatic amines (e.g., benzidine, methylene) and they are potential carcinogens (Raval et al. 2016), wherefore the attention is focused on the removal of dye from aqueous solutions. The biosorption mechanisms depends on the type of functional groups on the surface of the biomass and the nature of the metal. The main goal of such studies is to examine the possibilities for producing novel and cheaper forms of sorbents with standard or even better properties. The majority of biosorbents explored in previous studies were small particles with low density, poor mechanical strength and small hardness, which resulted in difficult post-separation of the treated effluent from the biosorbents especially in the practical application.

The aim of this work is synthesis of new xanthated biosorbent based on corn cob. In this biosorbent, xanthate groups (strong acid) are introduced in the structure of basic corn cob biomass by xanthation and sorption characteristics and abilities of material were improved. These negative charged groups have a high affinity for binding of cations. Obtained biosorbent will be applied for the removal of $\mathrm{Cr}(\mathrm{III})$ ions and methylene blue (MB) from aqueous solutions. There are no studies of the $\mathrm{Cr}$ (III) ions and methylene blue removal by xanthated biosorbents, especially corn cob, as well as using of xanthated biosorbents for wastewater purification. Xanthated corn cob (xCC) shows higher affinity and sorption capacity (about 5 times higher) for binding $\mathrm{Cr}$ (III) ions and methylene blue than basic corn cob biosorbent (CC), which predominantly has only weak acid carboxylic and phenolic groups.

The effect of various experimental parameters on the biosorption removal of $\mathrm{Cr}(\mathrm{III})$ and $\mathrm{MB}$ by xCC, such as contact time, initial $\mathrm{pH}$, initial metal ion concentration, biosorbent dose, particle size, temperature, stirring speed, were investigated. Biosorption process was described by fitting the experimental points using equilibrium, kinetic and thermodynamic models. Obtained kinetic and equilibrium experimental data were modeling by nonlinear fitting which better represent real conditions and phenomena which happen during sorption process, than linear models (Ho 2006). In order to determine the rate-controlling step in the overall process of biosorption, kinetic data were also examined by intra-particle diffusion model and Chrastil's model. Scanning electron microscopy (SEM), energy dispersive X-ray analysis (EDX) and Fourier transform infrared spectroscopy (FTIR) were used to investigate characteristics of xanthated biosorbent (xCC) and its interaction with $\mathrm{Cr}(\mathrm{III})$ ions and methylene blue (MB). In this work will be also presented a new specific laboratory system for biosorption treatment, which can be directly used for continuous process of polluted water in rinsing water baths in galvanization and similar processes. This work includes prediction and designing of purification process based on detailed equilibrium studies and mathematical tools for results interpretation.

\section{Materials and methods}

\subsection{Reagents}

All chemicals were of reagent grade and used without further refinement. $\mathrm{HNO}_{3}, \mathrm{NaOH}, \mathrm{CS}_{2}, \mathrm{Cr}\left(\mathrm{NO}_{3}\right)_{3} \cdot 9 \mathrm{H}_{2} \mathrm{O}$ were purchased from Merck (Germany). All solutions were prepared with deionized water (18 M $\Omega$ ). Methylene blue (Riedel de Haen, Germany) was used without further purification. Standard metal and dye stock solution was prepared by dissolving given amounts of pure $\mathrm{Cr}\left(\mathrm{NO}_{3}\right)_{3} \cdot 9 \mathrm{H}_{2} \mathrm{O}$ and methylene blue. All standard solutions were stored in a refrigerator at $+4^{\circ} \mathrm{C}$.

\subsection{Preparation of xanthated biosorbent}

Corn cob (Zea mays) used in the preparation of the xanthated biomass was harvested in October from a field near the town of Niš in Serbia. Zea mays was roughly crushed, washed with deionized water and grounded by laboratory mill (Waring, Germany). Zea mays were initially treated with diluted nitric acid and after that by sodium hydroxide, producing a basic corn cob (CC) (Stanković et al. 2012). Dried corn cob biomass was fractionized using standard sieves (Endecotts, England). Xanthation was carried out by following procedure: $10 \mathrm{~g}$ basic biomass, with granulation 
from 0.8 to $1.25 \mathrm{~mm}$, was soaked in $5 \mathrm{~mol} \mathrm{dm}^{-3} \mathrm{NaOH}$, stirred for 90 minutes and washed with deionized water. This material was then esterified with $1.0 \mathrm{~cm}^{3}$ of $\mathrm{CS}_{2}$ and $50 \mathrm{~cm}^{3} 2.5 \mathrm{~mol} \mathrm{dm}{ }^{-3} \mathrm{NaOH}$ for another $180 \mathrm{~min}$. Xanthated material was allowed to settle and separated by decantation and filtration. Synthesized xanthate was washed with water several times to remove excess alkali until $\mathrm{pH}$ of water became neutral, which was followed by washing with acetone. The material was stored in an airtight plastic container for further use (Kostić et al. 2013).

\subsection{Batch biosorption experiments}

Batch mode sorption experiments were carried out with $1.0 \mathrm{~g}$ sorbent in $250 \mathrm{~cm}^{3}$ of $\mathrm{Cr}$ (III) solution and $0.25 \mathrm{~g}$ sorbent in $250 \mathrm{~cm}^{3}$ of $\mathrm{MB}$ solution and $250 \mathrm{~cm}^{3}$ of in $400 \mathrm{~cm}^{3}$ Erlenmeyer flasks with an agitation rate of $200 \mathrm{rpm}$ and temperature $20^{\circ} \mathrm{C}$. To study the effect of $\mathrm{pH}$, the $\mathrm{Cr}(\mathrm{III})$ and $\mathrm{MB}$ solution $\left(50\right.$ and $100 \mathrm{mg} \mathrm{dm}^{-3}$, respectively) was adjusted to the desired $\mathrm{pH}$ (2.0 - 6.0 for $\mathrm{Cr}(\mathrm{III})$ ions and 2-10 for $\mathrm{MB}$ ) with $\mathrm{HNO}_{3}$ or $\mathrm{NaOH}$ using a pH-meter (SensIon5, $\mathrm{HACH}, \mathrm{USA}$ ). The $\mathrm{pH}$ was maintained during treatment and kept to within \pm 0.2 units by adding 0.01 or $0.1 \mathrm{~mol} \mathrm{dm}^{-}$ ${ }^{3} \mathrm{HNO}_{3}$ in small portions. The effect of particle size $\mathrm{xCC}$ on biosorption was assessed in $\mathrm{Cr}(\mathrm{III})$ and $\mathrm{MB}$ solution at $50 \mathrm{mg} \mathrm{dm}^{-3}$ initial $\mathrm{Cr}(\mathrm{III})$ concentration and $100 \mathrm{mg} \mathrm{dm}^{-3} \mathrm{MB}, \mathrm{pH} 5.0$, with different particle sizes ranging from 0.1$0.4 \mathrm{~mm}$ to $2.5-4.0 \mathrm{~mm}$, at $20^{\circ} \mathrm{C}$ and stirring speed $200 \mathrm{rpm}$. The effect of variation in the sorbent dose from 0.5 to $8 \mathrm{~g}$ $\mathrm{dm}^{-3}$ on the sorption of $50 \mathrm{mg} \mathrm{dm}^{-3}$ initial $\mathrm{Cr}$ (III) concentration and $100 \mathrm{mg} \mathrm{dm}^{-3} \mathrm{MB}$ at constant values of $\mathrm{pH} 5$ and stirring speed $200 \mathrm{rpm}$ was studied. The effect of stirring speed (the stirring speed varied from 50 to $600 \mathrm{rpm}$ ) on removal of $\mathrm{Cr}(\mathrm{III})$ ions and $\mathrm{MB}$ with $\mathrm{xCC}$ biomass was carried out at $\mathrm{pH} 5.0$ using $50.0 \mathrm{mg} \mathrm{dm}^{-3} \mathrm{Cr}(\mathrm{III})$ and $100 \mathrm{mg}$ $\mathrm{dm}^{-3} \mathrm{MB}$ solutions. For the equilibrium and kinetic biosorption studies, $\mathrm{xCC}$ biomass $\left(4 \mathrm{~g} \mathrm{dm}^{-3}\right)$ was mixed with $\mathrm{Cr}(\mathrm{III})$ solution of different initial Cr(III) concentrations (10, 20, 50, 100, 200 and $\left.400 \mathrm{mg} \mathrm{dm}^{-3}\right)$ and XCC biomass $\left(1 \mathrm{~g} \mathrm{dm}^{-3}\right)$ was mixed with MB solution of different initial MB concentrations (100, 150, 200, 250 and $\left.400 \mathrm{mg} \mathrm{dm}^{-3}\right)$ at 10, 20, 30 and $40^{\circ} \mathrm{C}$ in thermostated bath (Refrigerated/Heating Circulator, Julabo F12-ED, Germany), with constant agitation at $200 \mathrm{rpm}$ for $180 \mathrm{~min}$ to ensure biosorption equilibrium. Residual $\mathrm{Cr}$ (III) ions concentrations in all samples were measured using air-acetylene flame atomic absorption spectrometer. Residual MB concentrations in all samples were measured using UV-vis spectrophotometer. The amount of metal and dye sorbed $q_{\mathrm{t}}\left(\mathrm{mg} \mathrm{g}^{-1}\right)$ was determined by using the following equation:

$$
q_{\mathrm{t}}=\frac{\left(c_{0}-c_{\mathrm{t}}\right) \times V}{m}
$$

Where $c_{0}$ and $c_{\mathrm{t}}$ are the initial and final concentrations of the metal ion and dye in solution $\left(\mathrm{mg} \mathrm{dm}^{-3}\right), V$ is the solution volume $\left(\mathrm{dm}^{3}\right)$ and $m$ is the mass of the sorbent $(\mathrm{g})$.

The removal efficiency (RE) of metal ions and dye was calculated using equation (2):

$$
\mathrm{RE} \%=\frac{c_{0}-c_{\mathrm{t}}}{c_{0}} \times 100
$$

where $c_{0}$ and $c_{\mathrm{t}}$ are the initial and final concentrations of the metal ion and dye in the solution $\left(\mathrm{mg} \mathrm{dm}^{-3}\right)$, respectively.

The prediction of purification process and verification of theoretically calculated amounts of sorbent for purification of wastewater were carried out in batch conditions i.e. laboratory system with packed-bed column and recirculation of the aqueous phase. The sorption experiments were conducted in a transparent cylindrical polypropylene column. Appropriate i.e. calculated amount of xCC was packed between two discs of sintered alumina into a $200 \mathrm{~mm}$ length column. $\mathrm{Cr}(\mathrm{III})$ ions and $\mathrm{MB}$ solutions were pumped from the bottom of the column to the top using a peristaltic pump model SP 311 (VELP Scientifica, Italy). Samples were collected from the exit of the column after 0, 1, 5, 10, 20, 40, 90, 120 and 180 min and analyzed for the residual concentrations of $\mathrm{Cr}(\mathrm{III})$ ions and $\mathrm{MB}$, as described above. The different volume of the wastewater (from 1 to $5 \mathrm{dm}^{3}$ ) and desired removal efficiency were simulated in order to predict the required amount of sorbent for subsequent purification of wastewater with known concentration of $\mathrm{Cr}(\mathrm{III})$ ions and MB (114 $\mathrm{mg} \mathrm{dm}^{-3}$ for $\mathrm{Cr}(\mathrm{III})$ ions and $100 \mathrm{mg} \mathrm{dm}^{-3}$ for $\mathrm{MB}$ ). 


\subsection{Analysis}

$\mathrm{Cr}$ (III) concentrations in the samples were measured using atomic absorption spectrophotometry (AAnalyst 300; Perkin Elmer, USA), after filtration through a $0.45 \mu \mathrm{m}$ membrane (Agilent Technologies, Germany). MB concentrations of the samples were measured using spectrophotometer Shimadzu UV-vis 1650 PC (Shimadzu, Japan). Infrared spectrum of native biomass and $\mathrm{xCC}$ was obtained using a Fourier transform infrared spectrometer (Bomem Hartmann \& Braun MB-100 spectrometer). The morphology of the xCC surface was analyzed by scanning electron microscopy (SEM) (Hitachi SU8030). EDX analysis (Thermo Scientific NORAN System 7, USA) provides elemental information via analysis of X-ray emissions from the sorbent surface. Elemental composition was analyzed by elemental analysis on a Perkin Elmer series II CHNS/O System Analyzer 2400.

\section{Results and discussion}

\subsection{FTIR, SEM and EDX characterization of the $\mathrm{xCC}$}

FTIR analysis of basic CC and xCC is represented in Fig. 1. The very strong sorption band at around $3438 \mathrm{~cm}^{-1}$ from CC corresponds to hydroxyl groups on the biomass surface. The sorption band around $2921 \mathrm{~cm}^{-1}$ for basic CC corresponds to $\mathrm{C}-\mathrm{H}$ stretching of $\mathrm{CH}_{2}$ groups. The peaks near 1636 and $1458 \mathrm{~cm}^{-1}$ for $\mathrm{CC}$ are due to asymmetric and symmetric stretching vibration of $\mathrm{C}=\mathrm{O}$ in ionic carboxylic groups (-COO-). Aliphatic acid group vibration at $1252 \mathrm{~cm}^{-}$

${ }^{1}$ may be assigned to deformation vibration of $\mathrm{C}=\mathrm{O}$ and stretching vibration of $-\mathrm{OH}$ of carboxylic acids and phenols. The intense band at $1042 \mathrm{~cm}^{-1}$ is related to the $\mathrm{C}-\mathrm{OH}$ stretching vibration of alcoholic groups and carboxylic acids. The presence of sulfur groups in spectrum the $\mathrm{xCC}$ has been identified by the appearance of new peaks at 600,1025 and $1159 \mathrm{~cm}^{-1}$ corresponding to $\mathrm{C}-\mathrm{S}, \mathrm{C}=\mathrm{S}$ and $\mathrm{S}-\mathrm{C}-\mathrm{S}$. The peak at $1252 \mathrm{~cm}^{-1}$, present in the spectrum of CC, was disappeared in spectrum of XCC, which may indicate that this group can be involved in the synthesis process of xanthate groups.

\section{Fig. 1. FTIR spectra of $\mathrm{CC}$ and $\mathrm{xCC}(\mathrm{b}, \mathrm{c})$.}

The SEM image and EDX analysis of xCC and loaded xCC with $\mathrm{Cr}(\mathrm{III})$ ions and MB, is shown in Fig. 2. The SEM images (Fig. 2) shows a porous morphology of unloaded and loaded $\mathrm{Cr}$ (III) ions material, the external surface is full of cavities with pores of different sizes and shapes (irregular tubular structure with cavity $10-30 \mu \mathrm{m}$ in diameter for $\mathrm{xCC}$ ). The presence of macropores increases possibility of penetration and sorption of $\mathrm{Cr}(\mathrm{III})$ ions and $\mathrm{MB}$ through $\mathrm{xCC}$ with the diffusion.

EDX analysis and elemental composition before and after sorption of $\mathrm{Cr}(\mathrm{III})$ ions on $\mathrm{xCC}$ were shown in Fig. 2. The elemental composition of $\mathrm{xCC}$ is in accordance with the chemical composition of lignocellulosic materials. The presence of sulphur peaks in EDX spectra of $\mathrm{xCC}$ indicated emergence of xanthate group on the sorbent. After loading of $\mathrm{Cr}$ (III) ions the presence of characteristic signal for Cr in EDX spectra (Fig. 2b) was observed, thus suggesting that the $\mathrm{Cr}$ was sorbed onto $\mathrm{xCC}$. The percentage of $\mathrm{Na}$ in $\mathrm{xCC}$ was visibly changed after the sorption of the $\mathrm{Cr}(\mathrm{III})$ ions which indicates that ion-exchange probably existed in the sorption process.

Fig. 2. (a) The morphology surface and EDX analysis of xCC; (b) $\mathrm{Cr}$ (III) ions loaded on xCC; (c) The morphology surface of MB loaded on XCC.

Physical characteristics and elemental analysis of xCC are summarized in Table 1. 
Table 1. Physical characteristics and elemental analysis of xCC

\begin{tabular}{|l|c|}
\hline Characteristics & xCC \\
\hline Moisture $(\%)$ & 5.36 \\
\hline Ash $(\%)$ & 0.95 \\
\hline Bulk density $\left(\mathrm{kg} \mathrm{m}^{-3}\right)$ & 275.75 \\
\hline pHpzc & 7.19 \\
\hline $\mathrm{CEC}\left(\mathrm{cmol}(+) \mathrm{kg}^{-1}\right)$ & 20.2 \\
\hline $\mathrm{C}(\%)$ & 47.17 \\
\hline $\mathrm{O}(\%)$ & 44.09 \\
\hline $\mathrm{H}(\%)$ & 6.18 \\
\hline $\mathrm{N}(\%)$ & 0.01 \\
\hline $\mathrm{S}(\%)$ & 2.55 \\
\hline
\end{tabular}

\subsection{Effect of initial $\mathrm{pH}$ on $\mathrm{Cr}$ (III) ions and $\mathrm{MB}$ removal}

The results of $\mathrm{Cr}(\mathrm{III})$ ions and $\mathrm{MB}$ sorption onto $\mathrm{xCC}$ at different $\mathrm{pH}$ values are illustrated in Fig. 3. The figure shows that at $\mathrm{pH} 2$, the sorption capacity of $\mathrm{Cr}(\mathrm{III})$ ions on $\mathrm{xCC}$ was minimum, after that large increase of sorption capacity of $\mathrm{Cr}$ (III) ions occurs, and at $\mathrm{pH} 5$, the removal was maximum. Similar conclusion was found for $\mathrm{Cr}(\mathrm{III})$ ions sorption onto aerobic granules (Yao et al. 2009). It is well known that the increase of $\mathrm{pH}$ solution reduces the competition between the $\mathrm{H}^{+}$and the $\mathrm{Cr}(\mathrm{III})$ ions, favoring sorption at high $\mathrm{pH}$, i.e. as $\mathrm{pH}$ rises sorbent surface becomes more negative and enables unobstructed binding. The biosorption of MB on $\mathrm{xCC}$ is low in acidic medium and with the increase of $\mathrm{pH}$, the sorption capacity for $\mathrm{MB}$ increases. When solution $\mathrm{pH}$ was increased up to 5, the sorption of $\mathrm{MB}$ rapidly increases, whereas in the range from 5 to 8 , there was only slightly increase by $\mathrm{pH}$. Therefore, $\mathrm{pH} 5$ was chosen to carry out further investigation which is in accordance with the obtained values for $\mathrm{pHpzc}$ (Table 1). The sorption efficiency at $\mathrm{pH}$ values below pHpzc is high, because of the presence of strong acid xanthate groups, which are not protonated in applied conditions. These negative groups have high-affinity for the binding of positive charged metal ions, even at a relatively low $\mathrm{pH}$, probably by means of the ion-exchange mechanism. At $\mathrm{pH}$ values about $\mathrm{pHpzc}$ the surface of the sorbent becomes negatively charged and the surface will be such so as to enhances the sorption with $\mathrm{Cr}(\mathrm{III})$ ions and $\mathrm{MB}$ as a cationic dye with xCC (Guiza 2017).

Fig. 3. Effect of $\mathrm{pH}$ on the removal efficiency of $\mathrm{Cr}(\mathrm{III})$ ions and $\mathrm{MB}$ onto $\mathrm{xCC}$. $c_{0}[\mathrm{Cr}(\mathrm{III})]=50.0 \mathrm{mg} \mathrm{dm}^{-3}$ and $c_{0}[\mathrm{MB}]=100 \mathrm{mg} \mathrm{dm}^{-3} \mathrm{MB}$, sorbent dose $4.0 \mathrm{~g} \mathrm{dm}^{-3}$ for removal $\mathrm{Cr}$ (III) ions and $1.0 \mathrm{~g} \mathrm{dm}^{-3}$ for removal MB, temperature $20.0 \pm 0.2{ }^{\circ} \mathrm{C}$ and stirring speed $200 \mathrm{rpm}$.

\subsection{Effect of sorbent dosage on $\mathrm{Cr}$ (III) ions and $\mathrm{MB}$ removal}

The effects of sorbent dose on removal efficiency and the removal efficiency per unit weight of sorbent (RE \%/dose) has also been investigated (Fig. 4), to define optimal sorbent dose. It was examined by varying the amount of xCC from 0.5 to $8.0 \mathrm{~g} \mathrm{dm}^{-3}$, while keeping another parameters constant. The results showed that with increase of sorbent dose from 0.5 to $8.0 \mathrm{~g} \mathrm{dm}^{-3}$ removal efficiency on $\mathrm{xCC}$ increases from 10 to $89 \%$ for $\mathrm{Cr}$ (III) ions and from 26 to 60 $\%$ for MB. With increase of sorbent dose increases surface area and the availability of sorption sites. The biggest changes were noted with increase of sorbent dose from 0.5 to $4.0 \mathrm{~g} \mathrm{dm}^{-3}$ when removal efficiency of $\mathrm{Cr}$ (III) ions increases from 10 to $83 \%$. The biggest changes were in the range of sorbent dose from 0.5 to $1.0 \mathrm{~g} \mathrm{dm}^{-3}$ when removal efficiency of MB increases from 25 to $51 \%$. A further increase in biosorbent dosage did not cause a significant improvement in sorption. There are many factors which can contribute to this phenomenon. Probably the most important is fact that some sorption sites remain unoccupied because of the overlapping or aggregation of biosorbent particles (decreasing in total sorbent surface area) (El Nemr et al. 2015; Hafshejani et al. 2015). 
However, with increasing sorbent dosage from 0.5 to $8.0 \mathrm{~g} \mathrm{dm}^{-3}$ (Fig. 4), the removal efficiency of $\mathrm{Cr}$ (III) ions and MB per unit weight of sorbent (RE \%/dose) decreased. In the case of $\mathrm{Cr}$ (III) ions for dose from 0.5 to $2.0 \mathrm{~g} \mathrm{dm}^{-3}$ and for MB from dose 0.5 to $1.0 \mathrm{~g} \mathrm{dm}^{-3}$, value of $\mathrm{RE} \% /$ dose is almost constant, with further decreasing. By comparison of presented results of change of RE \% and RE \%/dose, the dose of $4 \mathrm{~g} \mathrm{dm}^{-3}$ for removal $\mathrm{Cr}(\mathrm{III})$ ions and $1 \mathrm{~g} \mathrm{dm}^{-3}$ for removal MB was picked as optimal for all experiments.

Fig. 4. Effect of sorbent dosage on the removal efficiency and the removal efficiency per unit weight of sorbent of $\mathrm{Cr}$ (III) ions and $\mathrm{MB}$ onto $\mathrm{xCC}$. $c_{0}[\mathrm{Cr}(\mathrm{III})]=50.0 \mathrm{mg} \mathrm{dm}^{-3}$ and $c_{0}[\mathrm{MB}]=100 \mathrm{mg} \mathrm{dm}^{-3} \mathrm{MB}$, pH 5, temperature $20.0 \pm 0.2{ }^{\circ} \mathrm{C}$ and stirring speed $200 \mathrm{rpm}$.

\subsection{Effect of particle size on $\mathrm{Cr}(\mathrm{III})$ ions and $\mathrm{MB}$ removal}

The experiments were carried out for five different particle sizes of xCC: $0.1-0.4,0.4-0.8,0.8-1.25,1.25-2.5,2.5-4.0$ (showed in Fig. 5). With increasing particle size from $0.1-0.4$ to 2.5 - 4.0, removal efficiency decreased from 83.5 to $72.5 \%$ for removal $\mathrm{Cr}$ (III) ions and from 52.9 to $47.6 \%$ for removal MB onto xCC. In according with literature, reduce of particle size leads to increasing of effective surface area (Singh et al. 2008; Gilbert et al. 2011). The particle size $0.8-1.25 \mathrm{~mm}$ was selected for further experiments due to their high removal efficiency for $\mathrm{Cr}(\mathrm{III})$ ions, while smaller particles, beside insignificant better removal efficiency, were not suitable because it was more difficult to remove them from dispersion.

Fig. 5. Effect of particle size on the removal efficiency of $\mathrm{Cr}(\mathrm{III})$ ions onto $\mathrm{xCC}$. $c_{0}[\mathrm{Cr}(\mathrm{III})]=50.0 \mathrm{mg} \mathrm{dm}^{-3}$ and $c_{0}[\mathrm{MB}]=100 \mathrm{mg} \mathrm{dm}^{-3} \mathrm{MB}$, sorbent dose $4.0 \mathrm{~g} \mathrm{dm}^{-3}$ for removal $\mathrm{Cr}$ (III) ions and $1.0 \mathrm{~g} \mathrm{dm}^{-3}$ for removal $\mathrm{MB}$, temperature $20.0 \pm 0.2{ }^{\circ} \mathrm{C}$ and stirring speed $200 \mathrm{rpm}$.

\subsection{Effect of stirring speed on $\mathrm{Cr}$ (III) ions and MB removal}

The effect of stirring speed on removal efficiency of $\mathrm{Cr}(\mathrm{III})$ ions and $\mathrm{MB}$ was studied in the range from 100 to 600 rpm (Fig. 6). Optimal value of removal efficiency for $\mathrm{Cr}(\mathrm{III})$ ions and $\mathrm{MB}$ on $\mathrm{xCC}$ was obtained for a stirring speed of $200 \mathrm{rpm}$. Increasing stirring rate increases probability of collision between $\mathrm{Cr}(\mathrm{III})$ ions and sorbent particles, i.e. film boundary layer thickness, surrounding the sorbent particles decreases which results in a reduction in surface film resistance. However, at high stirring speed the suspension was no longer homogenous and vortex phenomena can occur (Selatnia et al. 2004). This is also supported by literature.

Fig. 6. Effect of stirring speed on the removal efficiency of $\mathrm{Cr}$ (III) ions onto xCC. $c_{0}[\mathrm{Cr}(\mathrm{III})]=50.0 \mathrm{mg} \mathrm{dm}^{-3}$ and $c_{0}[\mathrm{MB}]=100 \mathrm{mg} \mathrm{dm}^{-3} \mathrm{MB}$, sorbent dose $4.0 \mathrm{~g} \mathrm{dm}^{-3}$ for removal $\mathrm{Cr}(\mathrm{III})$ ions and $1.0 \mathrm{~g} \mathrm{dm}^{-3}$ for removal $\mathrm{MB}$ and temperature $20.0 \pm 0.2{ }^{\circ} \mathrm{C}$.

\subsection{Kinetic study}

In order to investigate the biosorption mechanism of $\mathrm{Cr}(\mathrm{III})$ ions and $\mathrm{MB}$ on $\mathrm{xCC}$ and rate-controlling steps, a kinetic investigation was conducted. The kinetic sorption constants were determined in terms of pseudo-first order, pseudosecond order, intraparticle diffusion and Chrastil's kinetic models.

The first-order rate expression of Lagergren states that the rate of occupation of sorption sites should be proportional to the number of unoccupied sites (Meseguer et al. 2016). The nonlinear form of this equation is:

$$
q_{t}=q_{e}\left(1-e^{-k_{1} t}\right)
$$

where $q_{\mathrm{e}}\left(\mathrm{mg} \mathrm{g}^{-1}\right)$ is the mass of metal ions sorbed at equilibrium, $q_{\mathrm{t}}\left(\mathrm{mg} \mathrm{g}^{-1}\right)$ is the mass of metal sorbed at time $t$, and $k_{1}\left(\mathrm{~min}^{-1}\right)$ is the pseudo-first order reaction rate equilibrium constant. 
The pseudo second-order equation is also based on the sorption capacity of the solid phase and nonlinear form of equation is expressed as follows (Deniz and Kepekci 2017):

$$
q_{t}=\frac{k_{2} q_{e}^{2} t}{1+k_{2} q_{e} t}
$$

where $k_{2}\left(\mathrm{~g} \mathrm{mg}^{-1} \mathrm{~min}^{-1}\right)$ is the rate constant of second order sorption.

Intraparticle diffusion equation was introduced to indicate the behavior of intraparticle diffusion as the rate-limiting step in the biosorption (Altenor et al. 2009). The intraparticle equation can be described as:

$$
q_{t}=K_{I D} t^{\frac{1}{2}}+C
$$

where $K_{\text {id }}\left(\mathrm{mg} \mathrm{g}^{-1} \mathrm{~min}^{-1 / 2}\right)$ is the internal diffusion coefficient, $C$ is the intercept and the foregoing parameters can be determined from a plot of $q_{\mathrm{t}}$ versus $t^{1 / 2}$ (values of intercept give an idea about the thickness of boundary layer).

Finally Chrastil's model is analyzed and Chrastil's equation can be described as:

$$
q_{t}=q_{e}\left(1-e^{-k_{C} A_{0} t}\right)^{n}
$$

where: $k_{\mathrm{c}}$ is a rate constant $\left(\mathrm{dm}^{3} \mathrm{~g}^{-1} \mathrm{~min}^{-1}\right)$, which depend of diffusion coefficients and sorption capacity of biosorbent, $A_{0}$ is dose of biosorbent $\left(\mathrm{g} \mathrm{dm}^{-3}\right)$ and $n$ is a heterogeneous structural diffusion resistance constant, which can be ranged from 0 to 1 . When diffusion resistance is small, $n$ tends to 1 and the reaction is of first order. If the system is strongly limited by diffusion resistance, $n$ is small. In addition, when $n>1$, a consecutive reaction order may be expected (Carrillo et al. 2005; Chrastil 1990).

Calculated correlation coefficients and kinetics parameters are shown in Table 2 and 3. The coefficient of correlation values for sorption $\mathrm{Cr}(\mathrm{III})$ ions on $\mathrm{xCC}$ were for pseudo first order in range from 0.954 to 0.985 and for pseudo second order kinetic from 0.990 to 1.000 , respectively (Table 2). It is clear that determination coefficients $\left(r^{2}\right)$ for pseudosecond order model is the largest. The sorption capacities calculated by pseudo-second order model are close to those determined by experiments, so that this model certainly describes the sorption kinetics of $\mathrm{Cr}$ (III) onto xCC. Similar kinetic results have been reported by other researchers (Elabbas et al. 2016; Iftikhar et al. 2009). In table 3 are shown the values of coefficients of correlation for the sorption of $\mathrm{MB}$ onto $\mathrm{xCC}$, which shows that the pseudo-first and pseudosecond models have a good agreement with experimental data. Therefore, it can be concluded that pseudo secondorder model something better can describe kinetics sorption for MB onto xCC. The sorption capacities calculated by the pseudo-first and pseudo-second model are close to those determined by experiments. 
Table 2. The values of kinetic parameters for applied kinetic models for sorption $\mathrm{Cr}$ (III) ions on xCC (sorbent dose $1.0 \mathrm{~g} \mathrm{dm}^{-3}$, temperature $20.0 \pm 0.2^{\circ} \mathrm{C}$ )

\begin{tabular}{ccccccc}
\hline Cr(III)ions & 10 & 20 & 50 & 100 & 200 & 400 \\
\hline$q_{\mathrm{e}}^{\text {exp }}$ & 2.285 & 4.600 & 10.325 & 14.100 & 16.450 & 17.062 \\
\hline$k_{1}$ & 0.145 & 0.142 & 0.153 & 0.197 & 0.184 & 0.166 \\
$q_{\text {cal }}$ & 2.228 & 4.428 & 9.981 & 13.481 & 15.525 & 16.198 \\
$r^{2}$ & 0.985 & 0.985 & 0.975 & 0.962 & 0.954 & 0.958 \\
\hline \multicolumn{7}{c}{ Pseudo-first order } \\
\hline$k_{2}$ & 0.224 & 0.215 & 0.244 & 0.328 & 0.299 & 0.269 \\
$q_{\text {cal }}$ & 2.380 & 4.744 & 10.618 & 14.255 & 16.469 & 17.211 \\
$r^{2}$ & 0.998 & 1.000 & 0.995 & 0.994 & 0.990 & 0.991 \\
\hline$q_{\mathrm{e}}$ & 2.270 & 4.519 & 10.240 & 13.953 & 16.190 & 16.847 \\
$n$ & 0.600 & 0.591 & 0.495 & 0.419 & 0.389 & 0.407 \\
$k_{\mathrm{c}}$ & 0.021 & 0.020 & 0.017 & 0.017 & 0.014 & 0.014 \\
$r^{2}$ & 0.997 & 0.996 & 0.999 & 0.997 & 0.994 & 0.997 \\
\hline$K_{\text {id1 }}$ & 0.567 & 1.100 & 2.439 & 3.760 & \\
$C_{1}$ & -0.046 & -0.082 & 0.081 & 0.188 & 0.274 & 0.149 \\
$r^{2}$ & 0.974 & 0.978 & 0.996 & 0.990 & 0.983 & 0.986 \\
$K_{\text {id2 }}$ & 0.185 & 0.318 & 0.678 & 0.799 & 0.805 & 0.985 \\
$C_{2}$ & 1.059 & 2.300 & 5.511 & 8.335 & 9.850 & 9.414 \\
$r^{2}$ & 0.960 & 0.872 & 0.869 & 0.999 & 0.991 & 0.949 \\
\hline
\end{tabular}

Table 3. The values of kinetic parameters for applied kinetic models for sorption MB on xCC (sorbent dose 1.0 $\mathrm{g} \mathrm{dm}^{-3}$, temperature $20.0 \pm 0.2^{\circ} \mathrm{C}$ )

\begin{tabular}{|c|c|c|c|c|c|}
\hline $\mathrm{MB}$ & 100 & 150 & 200 & 250 & 400 \\
\hline$q_{\mathrm{e}}^{\exp }$ & 51.500 & 65.300 & 73.956 & 79.580 & 82.320 \\
\hline \multicolumn{6}{|c|}{ Pseudo-first order } \\
\hline$k_{1}$ & 0.047 & 0.076 & 0.093 & 0.086 & 0.053 \\
\hline$q^{\text {cal }}$ & 50.259 & 61.496 & 70.044 & 75.184 & 79.581 \\
\hline$r^{2}$ & 0.995 & 0.980 & 0.984 & 0.982 & 0.992 \\
\hline \multicolumn{6}{|c|}{ Pseudo-second order } \\
\hline$k_{2}$ & 0.047 & 0.098 & 0.127 & 0.116 & 0.063 \\
\hline$q_{\mathrm{a}}^{\mathrm{cal}}$ & 58.601 & 68.775 & 77.149 & 83.206 & 91.618 \\
\hline$r^{2}$ & 0.995 & 0.999 & 1.000 & 0.999 & 0.998 \\
\hline \multicolumn{6}{|c|}{ Chrastil's model } \\
\hline$q_{\mathrm{e}}$ & 51.479 & 63.786 & 71.875 & 77.503 & 81.949 \\
\hline$n$ & 0.763 & 0.611 & 0.629 & 0.611 & 0.703 \\
\hline$k_{\mathrm{c}}$ & 0.034 & 0.040 & 0.054 & 0.047 & 0.034 \\
\hline$r^{2}$ & 1.000 & 0.994 & 0.996 & 0.996 & 0.999 \\
\hline \multicolumn{6}{|c|}{ Intraparticle diffusion model } \\
\hline$K_{\text {id1 }}$ & 6.858 & 9.311 & 11.062 & 11.587 & 11.196 \\
\hline$C_{1}$ & -2.053 & 0.786 & 2.444 & 2.216 & -1.948 \\
\hline$r^{2}$ & 0.988 & 0.959 & 0.949 & 0.956 & 0.991 \\
\hline$K_{\mathrm{id} 2}$ & 2.823 & 2.535 & 1.991 & 2.568 & 3.879 \\
\hline$C_{2}$ & 23.168 & 38.028 & 52.223 & 52.009 & 42.489 \\
\hline$r^{2}$ & 0.911 & 1.000 & 0.957 & 0.940 & 0.984 \\
\hline
\end{tabular}


Fig. 7a and $\mathrm{b}$ show the plot of amount of $\mathrm{Cr}(\mathrm{III})$ ions/MB sorbed, $q_{\mathrm{t}}$ versus $t^{1 / 2}$, for $\mathrm{Cr}(\mathrm{III})$ ions/xCC system and the $\mathrm{MB} / \mathrm{xCC}$ system. The kinetic data for all initial $\mathrm{Cr}(\mathrm{III})$ and $\mathrm{MB}$ concentrations were tested, and shows that the plot have three linear segments, initially curved portion, which suggest film diffusion and the subsequent linear portion attribute to the intraparticle diffusion. The second region corresponds to the gradual uptake, which reflects at the intraparticle diffusion as the rate-limiting step and increase in initial concentration will produce a higher concentration of gradient, which will cause faster diffusion and sorption. The final plateau indicates the equilibrium uptake which implicates that the intraparticle diffusion is not the only rate-controlling step.

The Chrastil's model, based on Eq. (6), was applied to all concentrations (non-linear regression analysis) and was shown in Table 2 and 3. The coefficients of determinations in all cases were very high $\left(r^{2}>0.99\right)$. The results obtained for the diffusion resistance coefficient values in range from 0.389 to 0.600 for removal of $\mathrm{Cr}$ (III) ions onto xCC and from 0.611 to 0.763 for removal MB onto xCC. This indicating that the sorption process of $\mathrm{Cr}$ (III) ions and $\mathrm{MB}$ on $\mathrm{xCC}$ is significantly limited by diffusion resistance. Lower values of $\mathrm{n}$ and higher values for $k \mathrm{c}$ at $\mathrm{Cr}(\mathrm{III})$ ions sorption indicate that the system is strongly limited by diffusion resistance probably due to the formation of trivalent chromium hydroxy species at $\mathrm{pH}>3.5$ (Karaoglu et al. 2010).

Fig. 7. a) Intraparticle diffusion plot for $\mathrm{Cr}$ (III) ions sorption on $\mathrm{xCC}$ (Sorbent dose $4.0 \mathrm{~g} \mathrm{dm}^{-3}, \mathrm{pH} 5.0$, stirring speed $200 \mathrm{rpm}$ and temperature $20.0 \pm 0 .{ }^{\circ} \mathrm{C}$ ) and b) Intraparticle diffusion plot for MB sorption on xCC (Sorbent dose $1.0 \mathrm{~g} \mathrm{dm}^{-3}, \mathrm{pH} 5.0$, stirring speed $200 \mathrm{rpm}$ and temperature $20.0 \pm 0.2{ }^{\circ} \mathrm{C}$ ).

\subsection{Sorption isotherms}

Several isotherm models have been used in the literature to describe the sorption equilibrium data, such as Langmuir (Koutahzadeh et al. 2013; Park and Chon 2016), Freundlich (Puchana-Rosero et al. 2016), Sips (Limousy et al. 2016), Hill (Woitovich Valetti and Picó 2016), Toth (Rafati et al. 2016), Khan (Khan et al. 1997) and Brouers - Sotolongo (Altenor et al. 2009). The nonlinear forms of the Langmuir (Eq. (7)), Freundlich (Eq. (8)), Sips (Eq. (9)), Hill (Eq. (10)), Toth (Eq. (11)), Khan (Eq. (12)) and Brouers - Sotolongo (Eq. (13)) models are represented below:

$$
\begin{aligned}
& q_{e}=\frac{q_{m} K_{L} c_{e}}{1+K_{L} c_{e}} \\
& q_{e}=K_{F} c_{e}^{\frac{1}{n}} \\
& q_{e}=\frac{q_{m}\left(b_{S} c_{e}\right)^{n}}{1+\left(b_{S} c_{e}\right)^{n}} \\
& q_{e}=\frac{q_{H} c_{e}^{n_{H}}}{K_{D}+c_{e}^{n_{H}}} \\
& q_{e}=\frac{K_{T} c_{e}}{\left(\mathrm{a}_{T}+c_{e}\right)^{1 / t}} \\
& q_{e}=\frac{a_{S} b_{K} c_{e}}{\left(1+b_{K} c_{e}\right)^{a_{K}}} \\
& q_{e}=q_{m}\left(1-e^{\left(-K_{w} c_{e}^{\alpha}\right)}\right)
\end{aligned}
$$

where $q_{\mathrm{e}}$ is the amount of heavy metal ions sorbed $\left(\mathrm{mg} \mathrm{g}^{-1}\right)$ by the sorbent at equilibrium time; $c_{\mathrm{e}}$ is the concentration $\left(\mathrm{mg} \mathrm{dm}^{-3}\right)$ of metal ions and dye at equilibrium time in solution; $q_{\mathrm{m}}$ is the maximum sorption capacity of sorbent ( $\mathrm{mg}$ $\left.\mathrm{g}^{-1}\right) ; K_{\mathrm{L}}$ is Langmuir constant related to the energy of sorption $\left(\mathrm{dm}^{-3} \mathrm{mg}^{-1}\right), K_{\mathrm{F}}$ is Freundlich equilibrium constant (mg $\left.\mathrm{g}^{-1}\right)\left(\mathrm{dm}^{3} \mathrm{mg}^{-1}\right)^{1 / \mathrm{n}}$ and $\mathrm{n}\left(\mathrm{g} \mathrm{dm}^{-3}\right)$ are exponent; $b_{\mathrm{S}}\left(\mathrm{dm}^{-3} \mathrm{mg}^{-1}\right)$ in Sips model is the affinity constant for sorption; $q_{\mathrm{H}}$ is 
Hill isotherm maximum uptake saturation $\left(\mathrm{mg} \mathrm{dm}^{-3}\right) ; n_{\mathrm{H}}$ is Hill cooperativity coefficient of the binding interaction and $K_{\mathrm{D}}$ is Hill constant in equitation of Hill model. $K_{\mathrm{T}}$ is Toth isotherm constant $\left(\mathrm{mg} \mathrm{g}^{-1}\right) ; a_{\mathrm{T}}$ is Toth isotherm constant $\left(\mathrm{dm}^{3}\right.$ $\left.\mathrm{mg}^{-1}\right) ; t$ is Toth isotherm constant; $q_{\mathrm{S}}$ is theoretical isotherm saturation capacity $\left(\mathrm{mg} \mathrm{g}^{-1}\right), b_{\mathrm{K}}$ is Khan isotherm model constant and $a_{\mathrm{K}}$ is Khan isotherm model exponent, $K_{\mathrm{W}}$ is Brouers-Sotolongo isotherm constant $\left(\left(\mathrm{mg} \mathrm{g}^{-1}\right)\left(\mathrm{dm}^{3} \mathrm{mg}^{-}\right.\right.$ $\left.{ }^{1}\right) 1 / \alpha$ ) and $\alpha$ is Brouers-Sotolongo model exponent.

The differences between all these models are reflected in the homogeneous or heterogeneous sorption, presence or not of a maximum sorption monolayer and the number of parameters to fit. The isotherm models were fitted with experimental data by non-linear modeling using Origin Pro 2016 and calculated results are shown in Table 4 and 5 . The isotherms models have been used to investigate the sorption equilibrium between the metal and dye solution and the solid phase (xCC). As it can be seen in Table 4 and 5, the coefficients of determinations $\left(r^{2}\right)$ obtained for Langmuir isotherms model in all cases were high $\left(r^{2}>0.97\right)$ for sorption $\mathrm{Cr}$ (III) ions and MB on xCC at all temperatures, but not the greatest. However, values $q_{\mathrm{m}}$ fitted by Langmuir isotherm model were closest to the experimentally obtained $q_{\mathrm{m}}$ values at temperature 10,20 and $30{ }^{\circ} \mathrm{C}$ for sorption $\mathrm{Cr}(\mathrm{III})$ ions on $\mathrm{xCC}$. At temperature of $40{ }^{\circ} \mathrm{C}$ the coefficients of determinations obtained for Sips and Hill isotherms models are greater than the coefficients of determinations obtained for Langmuir model and values $q_{\mathrm{m}}$ fitted by Sips and Hill isotherm model were closest to the experimentally obtained $q_{\mathrm{m}}$ value for sorption $\mathrm{Cr}$ (III) ions on xCC. The maximum sorption capacity predicted by the Langmuir $(16.49,16.81$, 16.63 and $17.13 \mathrm{mg} \mathrm{g}^{-1}$ for temperature $10,20,30$ and $40{ }^{\circ} \mathrm{C}$, respectively) and Sips and Hill $(16.70,17.52,17.53$ and $17.88 \mathrm{mg} \mathrm{g}^{-1}$ for temperature $10,20,30$ and $40{ }^{\circ} \mathrm{C}$, respectively) isotherms were approximately same as the experimentally obtained values $\left(16.5,17.06,17.03\right.$ and $17.30 \mathrm{mg} \mathrm{g}^{-1}$ for temperature $10,20,30$ and $40{ }^{\circ} \mathrm{C}$, respectively) or sorption $\mathrm{Cr}(\mathrm{III})$ ions onto xCC. From the table 5 it was observed that the Brouers - Sotolongo isotherms model beside Sips and Hill models gives the best fit to the experimental data for sorption MB on $\mathrm{xCC}$, which indicating to the presence of active sites with heterogeneous sorption interactions. It can be inferred that the sorption environment in xCC material was heterogeneous based on $\alpha$ (being related to the heterogeneity $\alpha<1$ ). The maximum sorption capacity predicted by Brouers - Sotolongo $\left(80.09,83.25,82.76\right.$ and $83.89 \mathrm{mg} \mathrm{g}^{-1}$ for temperature $10,20,30$ and $40{ }^{\circ} \mathrm{C}$, respectively) and Sips and Hill $\left(83.27,86.78,85.90\right.$ and $87.30 \mathrm{mg} \mathrm{g}^{-1}$ for temperature $10,20,30$ and $40{ }^{\circ} \mathrm{C}$, respectively) isotherms models were approximately same as the experimentally obtained values $(79.5,82.32,81.90$ and $82.8 \mathrm{mg} \mathrm{g}^{-1}$ for temperature $10,20,30$ and $40^{\circ} \mathrm{C}$, respectively) for sorption MB onto xCC. Considering the $q_{\mathrm{m}}$ values, Brouers-Sotolongo equation are the most adapted for fitting sorption isotherms of MB on the xCC.

Taking into consideration values $q_{\mathrm{m}}$ and $r^{2}$ obtained from non-linear regression of Langmuir isotherm models, sorption of $\mathrm{Cr}(\mathrm{III})$ ions and $\mathrm{MB}$ on $\mathrm{xCC}$ occurs on a homogeneous surface by monolayer sorption without any interaction between sorbed ions, which indicates that the chemical mechanism of sorption probably prevails. However, the fact is that Sips isotherm model (hybrid of Langmuir and Freundlich isotherm models that is based on the theory of a homogenous - heterogeneous sorbent surface) in good agreement with experimental data indicates that in high sorbate concentrations predicts monolayer sorption onto surface of sorbent like at the Langmuir isotherm, while at low sorbate concentration, it follows Freundlich isotherm. Hill model, describes the binding of different species onto homogeneous substrates i.e. ability ligand binding at one site on the macromolecule, may influence different binding sites on same macromolecule, while Brouers-Sotolongo isotherm was specifically developed for the complex and heterogeneous systems, makes it suitable to describe sorption phenomena involving sorbing materials with different chemical and structural characteristics which is the precisely case in this study. The Langmuir sorption model deviates primarily because it fails to account for the surface roughness of the sorbate and multi-layered sorption phenomenon. The results show that the $\mathrm{Cr}(\mathrm{III})$ ions and $\mathrm{MB}$ sorption onto $\mathrm{xCC}$ is complex process because of heterogeneous surface as a consequence of differences in size and shape of pores, cracks and pits and different functional groups (xanthate, carboxylic, hydroxyl etc.) so sorption between $\mathrm{Cr}(\mathrm{III})$ and $\mathrm{MB}$ on $\mathrm{xCC}$ occurs via different possible interactions mainly electrostatic attraction, ion exchange and complexation. Electrostatic interactions are clearly involved in $\mathrm{Cr}(\mathrm{III})$ ions and MB sorption mechanism. The acidic groups such as xanthate and carboxylic groups favor sorption due to electrostatic interactions between the $\mathrm{Cr}$ (III) ions and MB molecules and the deprotonated xanthate and carboxylic groups. Furthermore, ion-exchange is an important concept in biosorption mechanisms, the ion exchange reaction occurs between light metals such as $\mathrm{Na}^{+}$, which are released upon binding of a cation on $\mathrm{xCC}$. 
The coefficients of determinations for Freundlich, Toth and Khan isotherms models are relatively equal to or less compared to those of Langmuir, Sips, Hill and Brouers - Sotolongo models. The experimental $q_{\mathrm{m}}$ values did not agree with the calculated sorption capacity values obtained from the Freundlich, Toth and Khan isotherms models. From the analysis of all the isotherms and the knowledge of the most important parameters $\left(q_{\mathrm{m}}\right.$ and $\left.r^{2}\right)$, the comparison of tested models for the description of sorption equilibrium isotherms on $\mathrm{xCC}$ is as follows: Langmuir $\geq \operatorname{Sips} \geq$ Hill $>$ Brouers-Sotolongo $>$ Toth $\geq$ Khan $>$ Freundlich for $\mathrm{Cr}(\mathrm{III})$ ions and Brouers-Sotolongo $\geq$ Sips $\geq$ Hill $>$ Langmuir $>$ Toth $\geq$ Khan $>$ Freundlich for MB. The results show that maximum sorption capacity calculated for non-linear models increased as the temperature increases and at temperature of $40{ }^{\circ} \mathrm{C}$ reaches the maximum value and amounts $17.13 \mathrm{mg}$ $\mathrm{g}^{-1}$ (Langmuir) for sorption Cr(III) ions and $83.89 \mathrm{mg} \mathrm{g}^{-1}$ (Brouers - Sotolongo) for sorption MB on xCC, because the increase rate of diffusion of the sorbate molecules across the external boundary layer and in internal pores of the sorbent particles is the result of the reduced viscosity of the solution (micropores favor $\mathrm{Cr}(\mathrm{III})$ ions sorption, while mesopores favor MB sorption). In the similar conditions, at $25^{\circ} \mathrm{C}$, basic material (non-modified corn cob) show much smaller sorption capacity ( $3.22 \mathrm{mg} \mathrm{g}^{-1}$ for $\mathrm{Cr}(\mathrm{III})$ and $16.21 \mathrm{mg} \mathrm{g}^{-1}$ for MB), which confirm significance of chemical modification. Values for $K_{\mathrm{L}}$ and $K_{\mathrm{W}}$ increase with increasing of temperature from 10 to $40{ }^{\circ} \mathrm{C}$ that indicates that the $\mathrm{Cr}(\mathrm{III})$ ions and MP are favorably sorbed by $\mathrm{xCC}$ at higher temperatures, i.e. the sorption process is endothermic. The separation factor $\left(R_{\mathrm{L}}\right)$ value determined from the Langmuir isotherm indicated that $\mathrm{Cr}(\mathrm{III})$ ions and $\mathrm{MB}$ sorption onto xCC were in favorable region $\left(R_{\mathrm{L}}<1\right)$. The decrease in $R_{\mathrm{L}}$ with an increase in the initial concentration indicates that the sorption is more favorable at high concentrations. The values of $n_{\mathrm{H}}$ for MP were $>1$, indicated the fact that the interaction of binding between MP and $\mathrm{xCC}$ was in the form of positive cooperativity.

Table 4. Parameters for Langmuir, Freundlich, Sips, Hill, Toth, Khan and Brouers - Sotolongo (B - S) isotherms models of $\mathrm{Cr}$ (III) ions sorption on $\mathrm{xCC}$

\begin{tabular}{|c|c|c|c|c|c|c|c|c|}
\hline Isotherm & \multicolumn{8}{|c|}{ Calculated parameters } \\
\hline Langmuir at $10^{\circ} \mathrm{C}$ & \multirow{4}{*}{$q_{\mathrm{m}}$} & 16.491 & \multirow{4}{*}{$K_{\mathrm{L}}$} & 0.158 & & & \multirow{24}{*}{$r^{2}$} & 0.996 \\
\hline Langmuir at $20^{\circ} \mathrm{C}$ & & 16.807 & & 0.191 & & & & 0.989 \\
\hline Langmuir at $30{ }^{\circ} \mathrm{C}$ & & 16.635 & & 0.210 & & & & 0.992 \\
\hline Langmuir at $40^{\circ} \mathrm{C}$ & & 17.130 & & 0.242 & & & & 0.987 \\
\hline Freundlich at $10{ }^{\circ} \mathrm{C}$ & \multirow{4}{*}{$K_{\mathrm{F}}$} & 4.885 & \multirow{4}{*}{$n$} & 4.394 & & & & 0.846 \\
\hline Freundlich at $20^{\circ} \mathrm{C}$ & & 5.236 & & 4.523 & & & & 0.863 \\
\hline Freundlich at $30^{\circ} \mathrm{C}$ & & 5.394 & & 4.659 & & & & 0.873 \\
\hline Freundlich at $40^{\circ} \mathrm{C}$ & & 5.960 & & 4.959 & & & & 0.843 \\
\hline Sips at $10^{\circ} \mathrm{C}$ & \multirow{4}{*}{$q_{\mathrm{m}}$} & 16.699 & \multirow{4}{*}{$b_{\mathrm{S}}$} & 0.151 & & 0.944 & & 0.994 \\
\hline Sips at $20^{\circ} \mathrm{C}$ & & 17.523 & & 0.162 & \multirow{3}{*}{$n_{\mathrm{S}}$} & 0.835 & & 0.993 \\
\hline Sips at $30^{\circ} \mathrm{C}$ & & 17.529 & & 0.173 & & 0.793 & & 0.998 \\
\hline Sips at $40^{\circ} \mathrm{C}$ & & 17.876 & & 0.212 & & 0.803 & & 0.994 \\
\hline Hill at $10^{\circ} \mathrm{C}$ & \multirow{4}{*}{$q_{\mathrm{H}}$} & 16.696 & \multirow{4}{*}{$n_{\mathrm{H}}$} & 0.945 & \multirow{4}{*}{$K_{\mathrm{D}}$} & 5.967 & & 0.994 \\
\hline Hill at $20^{\circ} \mathrm{C}$ & & 17.520 & & 0.835 & & 4.571 & & 0.993 \\
\hline Hill at $30^{\circ} \mathrm{C}$ & & 17.528 & & 0.793 & & 4.029 & & 0.998 \\
\hline Hill at $40^{\circ} \mathrm{C}$ & & 17.877 & & 0.803 & & 3.476 & & 0.994 \\
\hline Toth at $10^{\circ} \mathrm{C}$ & \multirow{4}{*}{$K_{\mathrm{T}}$} & 13.686 & \multirow{4}{*}{$a_{\mathrm{T}}$} & 5.0872 & \multirow{4}{*}{$t$} & 1.036 & & 0.996 \\
\hline Toth at $20^{\circ} \mathrm{C}$ & & 12.405 & & 3.460 & & 1.062 & & 0.996 \\
\hline Toth at $30^{\circ} \mathrm{C}$ & & 11.976 & & 2.921 & & 1.067 & & 0.999 \\
\hline Toth at $40^{\circ} \mathrm{C}$ & & 13.977 & & 2.970 & & 1.040 & & 0.987 \\
\hline Khan at $10^{\circ} \mathrm{C}$ & \multirow{4}{*}{$q_{\mathrm{s}}$} & 14.497 & \multirow{4}{*}{$b_{\mathrm{K}}$} & 0.196 & \multirow{4}{*}{$a_{\mathrm{K}}$} & 0.965 & & 0.996 \\
\hline Khan at $20^{\circ} \mathrm{C}$ & & 13.332 & & 0.289 & & 0.942 & & 0.996 \\
\hline Khan at $30^{\circ} \mathrm{C}$ & & 12.811 & & 0.342 & & 0.937 & & 0.999 \\
\hline Khan at $40^{\circ} \mathrm{C}$ & & 14.566 & & 0.337 & & 0.961 & & 0.987 \\
\hline
\end{tabular}




\begin{tabular}{|c|c|c|c|c|c|c|c|}
\hline B-S at $10^{\circ} \mathrm{C}$ & \multirow{4}{*}{$q_{\mathrm{m}}$} & 16.064 & \multirow{4}{*}{$K_{\mathrm{W}}$} & 0.194 & \multirow{4}{*}{$\alpha$} & 0.660 & 0.979 \\
\hline B-S at $20^{\circ} \mathrm{C}$ & & 16.717 & & 0.232 & & 0.595 & 0.981 \\
\hline B-S at $30^{\circ} \mathrm{C}$ & & 16.616 & & 0.254 & & 0.575 & 0.988 \\
\hline $\mathrm{B}-\mathrm{S}$ at $40^{\circ} \mathrm{C}$ & & 16.923 & & 0.271 & & 0.613 & 0.997 \\
\hline
\end{tabular}

Table 5. Parameters for Langmuir, Freundlich, Sips, Hill, Toth, Khan and Brouers - Sotolongo isotherms models of MB sorption on xCC.

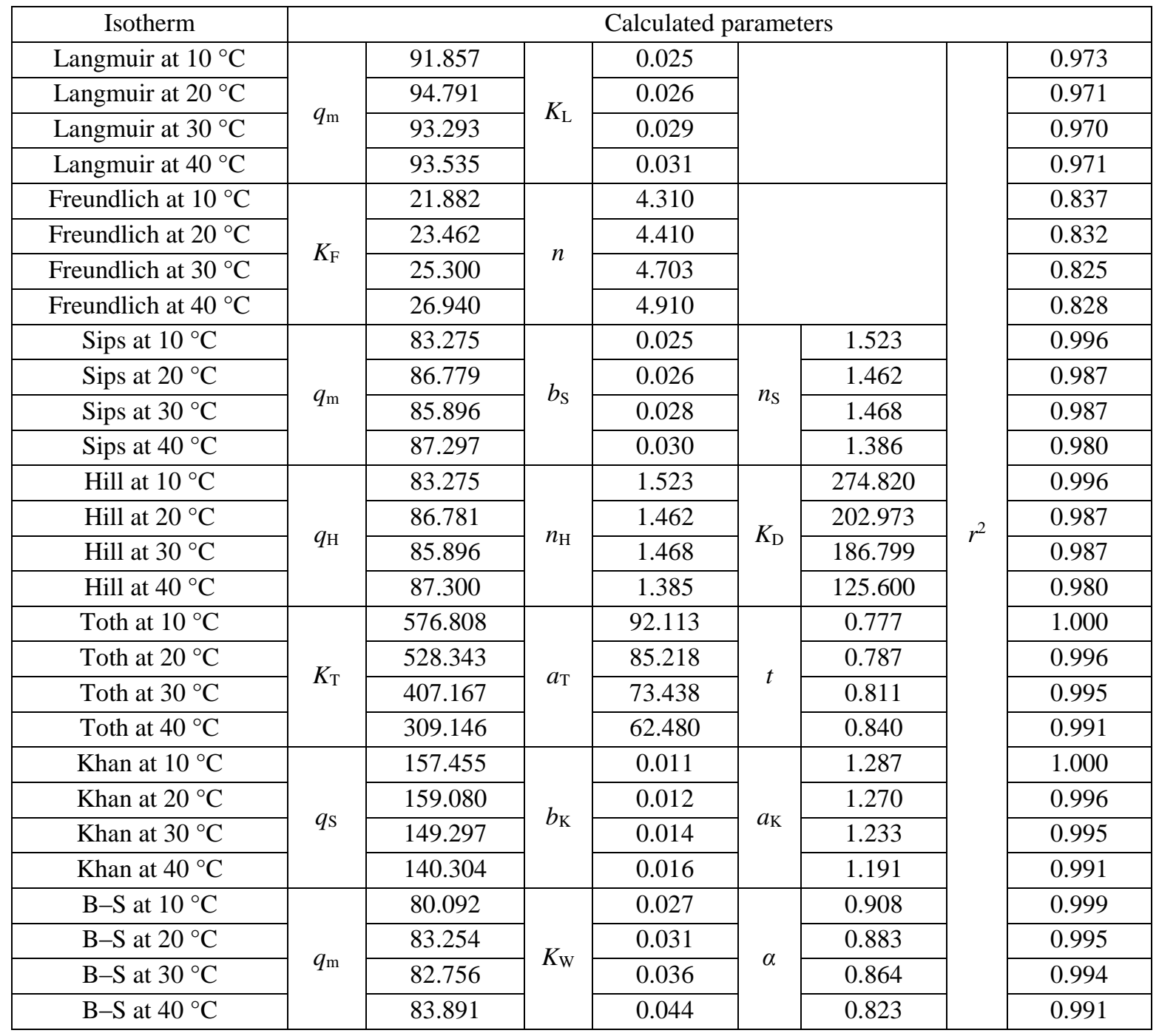

\subsection{Biosorption thermodynamics}

The thermodynamic parameters, including the free energy change $\left(\Delta G^{\circ}, \mathrm{kJ} \mathrm{mol}^{-1}\right)$, enthalpy change $\left(\Delta H^{\circ}, \mathrm{kJ} \mathrm{mol}^{-1}\right)$ and entropy change $\left(\Delta S^{\circ}, \mathrm{J} \mathrm{mol}^{-1}\right)$ can be estimated using equilibrium constant values as a function of temperature. The free energy change of the sorption reaction is given by the following equation (Kesraoui et al. 2016):

$$
\Delta G^{\circ}=-R T \ln K
$$

where $\Delta G^{\circ}$ is standard free energy change, $\mathrm{J} ; \mathrm{R}$ the universal gas constant, $8.314 \mathrm{~J} \mathrm{~mol}^{-1} \mathrm{~K}^{-1} ; T$ the absolute temperature, $\mathrm{K}$; and $K$ is the equilibrium constant obtained from the Langmuir model $\left(K_{\mathrm{L}}\right)$ for sorption $\mathrm{Cr}(\mathrm{III})$ ions and Brouers Sotolongo model $\left(K_{\mathrm{W}}\right)$ for sorption $\mathrm{MB}$ on $\mathrm{xCC}$. 
The free energy change indicates the degree of spontaneity of the sorption process and a higher negative value reflects more energetically favorable sorption process (Özer et al. 2004). The equilibrium constant may be expressed in terms of entropy change and enthalpy change as a function of temperature as follows (the van't Hoff equation):

$$
\Delta G=\frac{\Delta S^{\circ}}{R}-\frac{\Delta H^{\circ}}{R T}
$$

According this equation, the effect of temperature on the equilibrium constant $K$ is determined by the sign of $\Delta H^{\circ}$. Thus when $\Delta H^{\circ}$ is positive, i.e., when the sorption is endothermic, increase of temperature results in increase of $K$. Conversely, when $\Delta H^{\circ}$ is negative, i.e., when the sorption is exothermic, increase of temperature causes decrease of $K$. This implies shifting of the sorption equilibrium to the left. The other useful parameters are $\Delta H^{\circ}$ and $\Delta S^{\circ}$ and they are given by:

$$
\Delta G=\Delta H^{\circ}-T \Delta S^{\circ}
$$

The standards enthalpy and entropy changes are determined from the slope and intercept of the plot of $\ln K$ versus $1000 / T$ (The plot of $\ln K$ versus 1000/T is given in supplementary data Figure S1), respectively and are summarized in Table 6.

\begin{tabular}{|c|c|c|c|c|c|c|c|}
\hline & $T\left[{ }^{\circ} \mathrm{C}\right]$ & $\begin{array}{c}q_{\mathrm{m}} \\
{\left[\mathrm{mg} \mathrm{g}^{-1}\right]}\end{array}$ & $\operatorname{Ln} K$ & $\begin{array}{c}r^{2} \\
\ln K \text { vs. } 1 / T\end{array}$ & $\begin{array}{c}\Delta G^{\circ} \\
{\left[\mathrm{kJ} \mathrm{mol}^{-1}\right]}\end{array}$ & $\begin{array}{c}\Delta H^{\circ} \\
{\left[\mathrm{kJ} \mathrm{mol}^{-1}\right]}\end{array}$ & $\begin{array}{c}\Delta S^{\circ} \\
{\left[\mathrm{J} \mathrm{mol}^{-1}\right]}\end{array}$ \\
\hline \multirow{4}{*}{ 无氖 } & 10 & 16.491 & 9.01439 & \multirow{4}{*}{0.982} & -21.22 & \multirow{4}{*}{10.19} & \multirow{4}{*}{111.03} \\
\hline & 20 & 16.807 & 9.20387 & & -22.43 & & \\
\hline & 30 & 16.635 & 9.30081 & & -23.44 & & \\
\hline & 40 & 17.130 & 9.44185 & & -24.58 & & \\
\hline \multirow{4}{*}{$\sum$} & 10 & 80.092 & 9.06560 & \multirow{4}{*}{0.973} & -21.34 & \multirow{4}{*}{11.63} & \multirow{4}{*}{116.31} \\
\hline & 20 & 83.254 & 9.20105 & & -22.42 & & \\
\hline & 30 & 82.756 & 9.34081 & & -23.54 & & \\
\hline & 40 & 83.891 & 9.54705 & & -24.86 & & \\
\hline
\end{tabular}

Table 6. Thermodynamic parameters for the sorption of $\mathrm{Cr}(\mathrm{III})$ ions and MB onto xCC.

The $r^{2}$ values of the linear fitting experimental data were $>0.98$, that indicates the values of enthalpy and entropy change calculated for sorption $\mathrm{Cr}(\mathrm{III})$ ions and $\mathrm{MB}$ on $\mathrm{xCC}$ are fairly confident. The values $K$ increase by increasing of temperature suggesting that the sorption process is endothermic and the sorption capacity increases with increasing of temperature. Increase of temperatures leads to increasing of the sorption capacity, which may be attributed to the enlargement of pore size and activation of the sorbent surface. The negative $\Delta G^{\circ}$ value at all temperatures point out that sorption processes were spontaneous nature and feasible, by increasing the temperature the value of $\Delta G^{\circ}$ becomes more negative, suggesting that higher temperature makes the sorption favorable ( $\mathrm{Li}$ et al. 2015). The positive values of $\Delta H^{\circ}$ (about $10 \mathrm{~kJ}$ mol-1) show that the nature of sorption is endothermic and suggest that the sorption is physicochemical process (Elabbas et al. 2016). The positive values of $\Delta S^{\circ}$ also indicate the possibility of some structural changes, increase in disorder of system's interface and maybe indicate that ion replacement reaction is taking place. The positive value of $\Delta S^{\circ}$ suggests the process is enthalpy driven. Similar results were also reported by other researchers (Sawalha et al. 2006; Elabbas et al. 2016).

\subsection{Removal of $\mathrm{Cr}$ (III) ions and MB from wastewater}

The removal efficiency of $\mathrm{Cr}(\mathrm{III})$ ions and $\mathrm{MB}$, as well as amount of xanthated biosorbent could be predicted based on equilibrium data and mathematical tools for results interpretation. For predicting performances of sorption based on sorption isotherms (Langmuir and Brouers - Sotolongo) two equations were used (16 and 17), obtained by combining equation 1 with equations 7 and 9. 


$$
\begin{aligned}
& \frac{m}{V}=\frac{c_{0}-c_{t}}{q_{m}}=\frac{c_{0}-c_{t}}{\frac{q_{m} K_{L} c_{e}}{1+K_{L} c_{e}}} \\
& \frac{m}{V}=\frac{c_{0}-c_{t}}{q_{m}}=\frac{c_{0}-c_{t}}{q_{m}\left(1-e^{\left(-K_{w} C_{e}^{\alpha}\right)}\right)}
\end{aligned}
$$

The plots obtained from Eq. 16 and 17 (Fig. 8 a) and b)) indicate the predicted amount of xCC required for removing $\mathrm{Cr}$ (III) ions and MB from solutions (initial concentration of $\mathrm{Cr}$ (III) ions was $20 \mathrm{mg} \mathrm{dm}^{-3}$ and of MB was $100 \mathrm{mg} \mathrm{dm}^{-}$ $\left.{ }^{3}\right)$ to the extent of $80-99 \%$ removal for different solution volumes $\left(1-5 \mathrm{dm}^{3}\right)$.

\section{Fig 8. The predicted amount of $\mathrm{xCC}$ for the sorption of: a) $\mathrm{Cr}$ (III) ions and b) $\mathrm{MB}$, at temperature $20^{\circ} \mathrm{C}$.}

For example, from Fig. 8 it can be seen that for removal efficiency of $99 \%$ for volumes 1, 2, 3, 4 and $5 \mathrm{dm}^{-3}$ the amounts of $\mathrm{xCC}$ were 1.18, 2.36, 3.53, 4.71, 5.89 and 1.19, 2.38, 3.57, 4.76, $5.95 \mathrm{~g}$ for $\mathrm{Cr}(\mathrm{III})$ and $\mathrm{MB}$ solution, respectively. However, in the experimental results obtained with the same amount of sorbent, there was a slightly higher removal efficiency, on average about $5 \%$.

In the chrome plating industry, the plated metal parts are rinsed with water in one or more rinsing baths. In this study, treatment of effluent from rinsing baths of chrome plating line is carried out by continuous circulating of effluent through the column. After saturation, the column would be changed or there would be second column with by-bass which enable continuous process. The concentration of $\mathrm{Cr}$ (III) ions in tanks must be reduced to the level in accordance with environmental regulations for various types of water and industrial wastewaters, before discharging. This wastewater from chrome plating industry contains chrome in the range from 80 to $160 \mathrm{mg} \mathrm{dm}^{-3}$. In the case of this study wastewater was from chrome plating company Galpres, Leskovac, contains $\mathrm{Cr}$ in concentration of $114 \mathrm{mg} \mathrm{dm}^{-}$ ${ }^{3}$. Hexavalent chromium was reduced to $\mathrm{Cr}(\mathrm{III})$ by using chemical reducing agents such as sodium bisulfite at $\mathrm{pH}$ about 2.8 ( $\mathrm{pH}$ was adjusted to the desired $\mathrm{pH}$ with sulfuric acid). In the next step, $\mathrm{Ca}(\mathrm{OH})_{2}$ was added for $\mathrm{Cr}(\mathrm{III})$ precipitation as insoluble $\mathrm{Cr}(\mathrm{OH})_{3}$ at $\mathrm{pH}$ about 8 . After this stage, the concentration of $\mathrm{Cr}(\mathrm{III})$ ions was decreased to $7.5 \mathrm{mg} \mathrm{dm}^{-3}$. The verification of theoretically calculated amounts of sorbent was carried out by using packed-bed column laboratory system with recirculation of the aqueous phase. By previous prediction of purification process, calculated dose of $\mathrm{xCC}$ needed for effective removal (RE $100 \%$ ) of $\mathrm{Cr}$ (III) ions was $0.45 \mathrm{~g} \mathrm{dm}^{-3}$ for $1.0 \mathrm{dm}^{-3}$ of effluent with concentration $7.5 \mathrm{mg} \mathrm{dm}^{-3}$. The effluent, with initial $\mathrm{pH} 5.0$ and temperature $20{ }^{\circ} \mathrm{C}$, was treated in packed-bed column with recirculation of the aqueous phase. After 10 min concentration of $\mathrm{Cr}(\mathrm{III})$ ions decreased to $0.86 \mathrm{mg} \mathrm{dm}^{-3}$, after $20 \mathrm{~min}$ it was $0.21 \mathrm{mg} \mathrm{dm}^{-3}$ and after 40 min concentration of $\mathrm{Cr}(\mathrm{III})$ ions was lower than $0.1 \mathrm{mg} \mathrm{dm}^{-3}$.

To test the efficiency of $\mathrm{xCC}$ for removal of $\mathrm{MB}$ from contaminated water, the river water was used as the matrix of the sorption solution. By previous prediction of purification process, calculated dose of $\mathrm{xCC}$ needed for complete removal (RE $100 \%$ ) of MB was $1.20 \mathrm{~g}$ for $1.0 \mathrm{dm}^{-3}$ of the river water contaminated with $\mathrm{MB}$, with initial pH 5.0 and temperature $20^{\circ} \mathrm{C}$. The concentration of $\mathrm{MB}$ in sample was $100 \mathrm{mg} \mathrm{dm}^{-3}$. Treatment was conducted in system with packed-bed column with recirculation of the aqueous phase. Results shown that removal of MB from contaminated river water was very effective. The removal efficiency was $90 \%$ after $20 \mathrm{~min}$, and $94 \%$ after $40 \mathrm{~min}$, which is in a relatively good agreement with predicted value. Slightly lower value of the removal efficiency occurs due to presence of other contaminants in river water $(\mathrm{Ca}(\mathrm{II}), \mathrm{Mg}(\mathrm{II})$, organic matter etc.). Competition among ions for sorption sites could hinder $\mathrm{xCC}$ binding ability for $\mathrm{MB}$, as expected. The high removal efficiency of $\mathrm{MB}$ in river water by $\mathrm{xCC}$, indicates the great application potential of xantated biosorbent in removing of cationic pollutants from water. 


\section{Conclusion}

This study show that the xanthated corn cob has high potential as an efficient biosorbent for the removal of $\mathrm{Cr}(\mathrm{III})$ and methylene blue from water. The presence of the sulphur functional group on the sorbent surface was confirmed by FTIR and EDX analysis. The Cr(III) intake by xCC was confirmed by EDX analysis. The kinetic experimental data fitted very well to pseudo-second order and Chrastil's kinetic models, i.e. the sorption is under both reaction and diffusion control. The Langmuir model can describe the equilibrium data for biosorption of $\mathrm{Cr}(\mathrm{III})$ ions onto xCC and so the nature of sorption of $\mathrm{Cr}(\mathrm{III})$ ions on the sorbent is more compatible with Langmuir assumptions. However, the sorption of MB is better described with Brouers - Sotolongo isotherm model. The sorption mechanism of $\mathrm{Cr}(\mathrm{III})$ ions and $\mathrm{MB}$ onto $\mathrm{xCC}$ is complex process, from one side because of different sizes and shapes of pores on sorption surface, and from the other side because of different functional groups on the surface of xCC (xanthate, carboxylic, hydroxyl and other groups). The sorption of $\mathrm{Cr}(\mathrm{III})$ and $\mathrm{MB}$ onto $\mathrm{xCC}$ occurs via different possible interactions, mainly electrostatic attraction, ion exchange and complexation. Investigation of thermodynamics of the sorption of cations on $\mathrm{xCC}$ show that process is endothermic, feasible and spontaneous. The laboratory system with packed-bed column and recirculation of the aqueous phase, created in this study, can be used for purification of water in rinse baths in galvanization and similar processes, offering an alternative treatment for the removal of heavy metals and saving of process water.

The developed xCC biosorbent has demonstrated not only high sorption capacity and faster kinetics, it also has additional benefits like simple synthesis, absence of secondary pollution, cost-effectiveness and eco-friendliness. It can be proved to be a promising advanced sorbent for removal of cationic pollutants from contaminated natural and waste waters. The regeneration and desorption aspect of $\mathrm{xCC}$ needs further studies for its real cost effectiveness.

\section{Acknowledgement}

The authors would like to thank the Ministry of Education, Science and Technological Development of the Republic of Serbia for supporting this work (Grant no TR 34008).

\section{References}

Altenor S, Carene B, Emmanuel E, Lambert J, Ehrhardt JJ, Gaspard S (2009) Adsorption studies of methylene blue and phenol onto vetiver roots activated carbon prepared by chemical activation. J Hazard Mater 165:1029-1039.

Anderson RA (1997) Chromium as an essential nutrient for humans. Regul Toxicol Pharm 26:S35-41.

Bennett GF (2001) Industrial Waste Treatment Handbook: Frank Woodward, Butterworth-Heinemann, Woburn, MA. doi:10.1016/S0304-3894(01)00391-0.

Carrillo F, Lis MJ, Colom X, López-Mesas M, Valldeperas J (2005) Effect of alkali pretreatment on cellulase hydrolysis of wheat straw: Kinetic study. Process biochem 40:3360-3364.

Chojnacka K, Chojnacki A, Gorecka H (2005) Biosorption of $\mathrm{Cr}^{3+}, \mathrm{Cd}^{2+}$ and $\mathrm{Cu}^{2+}$ ions by blue-green algae Spirulina sp.: kinetics, equilibrium and the mechanism of the process. Chemosphere 59:75-84.

Chrastil J (1990) Adsorption of direct dyes on cotton: Kinetics of dyeing from finite baths based on new information. Text Res J 60:413-416.

Deniz F, Kepekci RA (2017) Bioremoval of Malachite green from water sample by forestry waste mixture as potential biosorbent. Microchem J 132:172-178.

El Nemr A, El-Sikaily A, Khaled A, Abdelwahab O (2015) Removal of toxic chromium from aqueous solution, wastewater and saline water by marine red alga Pterocladia capillacea and its activated carbon. Arab J Chem 8:105117. 
Elabbas S, Mandi L, Berrekhis F, Pons MN, Leclerc JP, Ouazzani N (2016) Removal of Cr(III) from chrome tanning wastewater by adsorption using two natural carbonaceous materials: Eggshell and powdered marble. J Environ Manage 166:589-595.

Gilbert A, Emmanuel I, Adebanjo A, Olalere G (2011) Biosorptive removal of $\mathrm{Pb}^{2+}$ and $\mathrm{Cd}^{2+}$ onto novel biosorbent: Defatted Carica papaya seeds. Biomass Bioenerg 35:2517-2525.

Guiza S. (2017) Biosorption of heavy metal from aqueous solution using cellulosic waste orange peel. Ecol Eng 99:134-140.

Gupta VK, Agarwal SH, Saleh TA (2011) Chromium removal by combining the magnetic properties of iron oxide with adsorption properties of carbon nanotubes. Water Res 45:2207-2212.

Hafshejani LD, Nasab SB, Gholami RM, Moradzadeh M, Izadpanah Z, Hafshejani SB, Bhatnagar A (2015) Removal of zinc and lead from aqueous solution by nanostructured cedar leaf ash as biosorbent. J Mol Liq 211:448-456.

Haque MA, ShamsUd-Din M, Haque M (2002) The effect of aqueous extracted wheat bran on the baking quality of biscuit. Int J Food Sci Technol 37:453-462.

Ho YS (2006) Isotherms for the sorption of lead onto peat: Comparison of linear and non-linear methods. Polish Journal of Environmental Studies 15(1):81-86.

Iftikhar AR, Bhatti HN, Hanif MA, Nadeem R (2009) Kinetic and thermodynamic aspects of $\mathrm{Cu}$ (II) and $\mathrm{Cr}$ (III) removal from aqueous solutions using rose waste biomass. J Hazard Mater 161:941-947.

Karaoglu MH, Zor S, Ugurlu M (2010) Biosorption of Cr(III) from solutions using vineyard pruning waste. Chem Eng J 159:98-106.

Kesraoui A, Moussa A, Ben Ali G, Seffen M (2016) Biosorption of alpacide blue from aqueous solution by lignocellulosic biomass: Luffa cylindrica fibers. Environ Sci Pollut Res 23:15832-15840.

Khan AR, Ataullah R, Al-Haddad A (1997) Equilibrium adsorption studies of some aromatic pollutants from dilute aqueous solutions on activated carbon at different temperatures. J Colloid Interface Sci 194:154-165.

Kostić M, Radović M, Mitrović J, Antonijević M, Bojić D, Petrović M, Bojić A (2013) Using xanthated Lagenaria vulgaris shell biosorbent for removal of $\mathrm{Pb}(\mathrm{II})$ ions from wastewater. J Iran Chem Soc 11(2):565-578.

Koutahzadeh N, Daneshvar E, Kousha M, Sohrabi MS, Bhatnagar A (2013) Biosorption of hexavalent chromium from aqueous solution by six brown macroalgae. Desalin Water Treat 51:6021-6030.

Li C, Zhong H, Wang S, Xue J, Zhang Z (2015) Removal of basic dye (methylene blue) from aqueous solution using zeolite synthesized from electrolytic manganese residue. J Ind Eng Chem 23:344-352.

Limousy L, Ghouma I, Ouederni A, Jeguirim M (2016) Amoxicillin removal from aqueous solution using activated carbon prepared by chemical activation of olive stone. Environ Sci Pollut Res. doi: 10.1007/s11356-016-7404-8.

Meseguer VF, Ortuño JF, Aguilar MI, Pinzón-Bedoya ML, Lloréns M, Sáez J, Pérez-Marín AB (2016). Biosorption of cadmium (II) from aqueous solutions by natural and modified non-living leaves of Posidonia oceanica. Environ Sci Pollut Res 23:24032-24046.

Michalak I, Chojnacka K, Witek-Krowiak A (2013) State of the art for the biosorption process - a review. Appl Biochem Biotechnol 170:1389-1416.

Naja GM, Volesky B (2009) Treatment of metal-bearing effluents: removal and recovery. Heavy Met Environ 247292.

Özer A, Özer D, Özer A (2004) The adsorption of copper(II) ions on to dehydrated wheat bran (DWB): determination of the equilibrium and thermodynamic parameters. Process Biochemistry 39:2183-2191. 
Park JH, Chon HT (2016) Characterization of cadmium biosorption by Exiguobacterium sp. isolated from farmland soil near Cu-Pb-Zn mine. Environ Sci Pollut Res 23:11814-11822.

Puchana-Rosero MJ, Lima EC, Ortiz-Monsalve S, Mella B, da Costa D, Poll E, Gutterres M (2016) Fungal biomass as biosorbent for the removal of Acid Blue 161 dye in aqueous solution. Environ Sci Pollut Res. doi: 10.1007/s11356016-8153-4.

Rafati L, Ehrampoush MH, Rafati AA, Mokhtari M, Mahvi AH (2016). Modeling of adsorption kinetic and equilibrium isotherms of naproxen onto functionalized nano-clay composite adsorbent. J. Mol. Liq. 224:832-841.

Rajput S, Pittman CU (2015) Magnetic magnetite $\left(\mathrm{Fe}_{3} \mathrm{O}_{4}\right)$ nanoparticle synthesis and applications for lead $\left(\mathrm{Pb}^{2+}\right)$ and chromium $\left(\mathrm{Cr}^{6+}\right)$ removal from water. J Colloid Interface Sci 468:334-346.

Rajurkar NS, Gokarn AN, Dimya K (2011) Adsorption of chromium (III), nickel (II), and copper (II) from aqueous solution by activated alumina. Clean Soil Air Water 39:767-773.

Raval NP, Shah PU, Shah NK (2016) Adsorptive amputation of hazardous azo dye Congo red from wastewater: a critical review. Environmental Science and Pollution Research, 23:14810-14853.

Sawalha MF, Peralta-Videa JR, Romero-González J, Gardea-Torresdey JL (2006) Biosorption of Cd(II), Cr(III), and $\mathrm{Cr}(\mathrm{VI})$ by saltbush (Atriplex canescens) biomass: Thermodynamic and isotherm studies. J Colloid Interface Sci 300:100-104.

Schiewer S, Volesky B (1995) Modelling of the proton-metal ion exchange in biosorption. Environ Sci Technol 29:3049-3058.

Selatnia A, Bakhti MZ (2005) Biosorption of $\mathrm{Cr}^{3+}$ from aqueous solution by a $\mathrm{NaOH}$-treated bacterial dead Streptomyces rimosus biomass. The European Journal of Mineral Processing and Environmental Protection 5:135146.

Selatnia A, Boukazoula A, Kechid N, Bakhti MZ, Chergui A, Kerchich Y (2004) Biosorption of lead(II) from aqueous solution by a bacterial dead Streptomyces rimosus biomass. Biochem Eng J 19:127-135.

Singh CK, Sahu JN, Mahalik KK, Mohanty CR, Mohan BR, Meikap BC (2008) Studies on the removal of Pb(II) from wastewater by activated carbon developed from Tamarind wood activated with sulphuric acid. J Hazard Mater 153:221-228.

Stanković M, Krstić N, Slipper I, Mitrović J, Radović M, Bojić D Bojić, A (2012) Chemically modified Lagenaria vulgaris as a biosorbent for the removal of $\mathrm{Cu}(\mathrm{II})$ from water. Austr $\mathrm{J}$ Chem 66(2):227-236.

Wang J, Chen C (2009) Biosorbents for heavy metals removal and their future, Biotechnol Adv 27:195-226.

Witek-Krowiak A, Harikishore Kumar Reddy D (2013) Removal of microelemental Cr(III) and Cu(II) by using soybean meal waste - Unusual isotherms and insights of binding mechanism. Bioresource Technology 127:350-357.

Woitovich Valetti N, Picó G (2016) Adsorption isotherms, kinetics and thermodynamic studies towards understanding the interaction between cross-linked alginate-guar gum matrix and chymotrypsin. J Chromatogr B 1012-1013:204210 .

Yao L, Ye ZF, Tong MP, Lai P, Ni JR (2009) Removal of $\mathrm{Cr}^{3+}$ from aqueous solution by biosorption with aerobic granules. J Hazard Mater 165:250-255.

Yun YS, Park D, Park JM, Volesky B (2001) Biosorption of trivalent chromium on the brown seaweed biomass. Environ Sci Technol 35:4353-4358. 